\title{
Analysis of Cash Ratio, Firm Size and Return on Assets that Influence Dividend Payout Ration Soe Companies Listed on the Indonesia Stock Exchange
}

\author{
Ester Sitepu \\ Department of Accounting, University of North Sumatra, Indonesia
}

\begin{tabular}{|c|c|}
\hline ARTICLE INFO & ABSTRACT \\
\hline Article history: & \multirow{4}{*}{$\begin{array}{l}\text { This study aims to determine whether the Influence cash ratio, firm } \\
\text { size and return on assets influence simultaneously and partially to } \\
\text { the dividend payout ratio At the state-owned company Listed on the } \\
\text { Indonesia Stock Exchange. The method of this thesis is a descriptive } \\
\text { statistical analysis, the classic assumption test, and hypothesis } \\
\text { testing. Independent variables in this study is the cash ratio, firm size } \\
\text { and return on assets while Dependent variable is the dividend } \\
\text { payout ratio with a sample size of this study as many as } 54 \text { by using } \\
\text { purposive sampling acquired } 18 \text { companies over three years. The } \\
\text { type of data used is secondary data. The results of this study } \\
\text { demonstrate that, in sumultaneous cash ratio, firm size and return on } \\
\text { assets has no effect simultaneous dividend payout ratio in the state- } \\
\text { owned company. In partial cash ratio, and return on assets have no } \\
\text { effect and firm size affect the dividend payout ratio. }\end{array}$} \\
\hline $\begin{array}{r}\text { Received Jan 10, } 2022 \\
\text { Revised Jan 28, } 2022 \\
\text { Accepted Feb 28, } 2022\end{array}$ & \\
\hline \multirow{4}{*}{$\begin{array}{r}\text { Keywords: } \\
\text { Cash Ratio; } \\
\text { Firm Size; } \\
\text { Return On Assets; } \\
\text { Dividend Payout Ratio. }\end{array}$} & \\
\hline & \\
\hline & 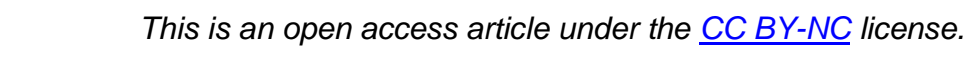 \\
\hline & (cc) (i) $\$$ \\
\hline \multicolumn{2}{|l|}{ Corresponding Author: } \\
\hline \multicolumn{2}{|c|}{$\begin{array}{l}\text { Ester Sitepu, } \\
\text { Department of Accounting, } \\
\text { University Of North Sumatara, Indonesia, } \\
\text { JI. Dr. Mansur No. } 9 \text { Padang Bulan, Kec. Medan Baru, Kota Medan } 20222 . \\
\text { Email: estersitepu@gmail.com }\end{array}$} \\
\hline
\end{tabular}

\section{INTRODUCTION}

Cash Ratiois a measure of the liquidity ratio, which is the company's ability to meet its current liabilities through the amount of cash (and cash equivalents, such as demand deposits or other deposits in banks that can be withdrawn at any time) owned by the company. The higher the CR indicates the company's cash ability to meet (pay) its short-term obligations (Brigham, 1983). With the increasing cash ratio, it can also increase the confidence of investors to pay dividend.

Firm Sizereflects that an established and large company has easier access to the capital market, while a small company is the opposite. Companies that can easily access the capital market will be able to get funds in a relatively fast time. Therefore, companies with a larger size are expected to have the ability to generate greater earnings, so that they will be able to pay higher dividends compared to small companies (Hatta, 2002).

Many studies have been done related to dividends. From these studies, there are several research gaps, including: Marlina and Danica (2009), in their research results show that ROA has a positive and significant influence on the DPR. This is in accordance with research conducted by Puspita (2009). The results of this study contradict the results of research conducted by Nuringsih (2005) which states that ROA has a negative effect on dividends. Meanwhile, research conducted by Sunarto (2004) states that partially ROA does not have a significant influence on the DPR. Research conducted by Sunarto and Kartika (2003) states that the Cash Ratio does not show a 
significant influence on the DPR, while research conducted by Puspita (2009) states that the Cash Ratio has a positive and significant effect on the Dividend Payout Ratio. Permatasari (2009) stated that Firm Size had a positive and significant effect on the DPR, Wardhani (2009) stated that Firm Size had a negative and insignificant effect on the DPR, while Habibie (2009) stated that Firm Size had no significant positive effect on the DPR.

\section{RESEARCH METHOD}

The type of research conducted is causal associative research. According to Umar (2003:30) "causal associative research is research that aims to analyze the relationship between one variable and another variable or how one variable affects other variables".

\subsection{Analysis Techniques}

a. Descriptive Statistical Analysis

Descriptive statistical analysis is a descriptive technique that provides information about the data held and does not intend to test hypotheses. This analysis is only used to present and analyze data accompanied by calculations in order to clarify the circumstances or characteristics of the data in question. The measurements used in this descriptive statistic include the number of samples, minimum value, maximum value, average value (mean), and standard deviation (Ghozali, 2011).

b. Classic assumption test

The data analysis method used in this study was a multiple regression analysis model using SPSS for windows software. The use of regression analysis method in testing the hypothesis, first tested whether the model meets the classical assumptions or not. The classical assumption test is a model that is said to be quite good and can be used as a predictive tool if it has the best linear unbisied estimator (BLUE) properties.

\section{RESULTS AND DISCUSSIONS}

\subsection{Research result}

a. Descriptive Statistical Analysis

Descriptive statistics provide an explanation of the minimum value, maximum value, average value (mean), and standard deviation values of the independent variables and dependent variables.

\begin{tabular}{cccccc}
\multicolumn{7}{c}{ Table 1. Descriptive Statistics Descriptive Statistics } \\
\hline & $\mathrm{N}$ & Minimum & Maximum & mean & Std. Deviation \\
\hline Dividend Payout Ratio & 54 & 10 & 55 & 25.28 & 9,488 \\
CR & 54 & 1.09 & 757.00 & $1.3844 \mathrm{E} 2$ & 106.73116 \\
SIZE & 54 & 5.96 & 28.06 & 16.1231 & 4.75907 \\
ROA & 54 & -5.50 & 17.40 & 4.7426 & 4.61318 \\
Valid N (listwise) & 54 & & & & \\
\hline
\end{tabular}

Source: SPSS processed data, 2016

From table 4.1, several things can be explained as described below:

a) The dividend pay out ratio $(\mathrm{Y})$ variable has a minimum value of 10 and a value of. 55 with an average of 25.28 and a standard deviation of 9,488 with a total of 54 observations.

b) The cash ratio variable (X2) has a minimum value of 1.09 and a maximum value of 757 , with an average of 1.384 and a standard deviation of 106.73116 with a total of 54 observations.

c) Firm size variable (X3) has a minimum value of 5.96 and a maximum value of 28.06 , with an average of 16.1231 and a standard deviation of 4.75907 with a total of 54 observations.

d) The Return on Assets (X1) variable has a minimum value of -5.50 and a maximum value of 17.40 with an average of 4.7426 and a standard deviation of 4.61318 with a total of 54 observations.

\section{b. Classical Assumption Test}

To produce a good regression model, regression analysis requires classical assumption testing before testing the hypothesis, so in this study it is necessary to test the classical assumptions first which includes: data normality test, multicollinearity test, heteroscedasticity test and autocorrelation test which are carried out as follows: 


\section{c. Data Normality Test}

The normality test aims to test whether the residual variables are normally distributed or not. The statistical test that can be used to test whether the residuals are normally distributed is the Kolmogorov-Smirnov (KS) non-parametric statistical test by making the following hypotheses:

$\mathrm{HO}$ : residual data is normally distributed

$\mathrm{Ha}$ : residual data is not normally distributed

If the significance value is greater than 0.05 then $\mathrm{HO}$ is accepted and vice versa if the significance value is less than 0.05 then $\mathrm{HO}$ is rejected or $\mathrm{Ha}$ is accepted.

Table 2. Normality Test Results

One-Sample Kolmogorov-Smirnov Test

\begin{tabular}{ccc}
\hline & & $\begin{array}{c}\text { Unstandardized } \\
\text { Residual }\end{array}$ \\
\hline $\mathrm{N}$ & & 54 \\
Normal Parameters & mean & .0000000 \\
& Std. Deviation & 8.92722414 \\
Most Extreme Differences & Absolute & .105 \\
& Positive & .105 \\
& negative & -.080 \\
Kolmogorov-Smirnov Z & & .773 \\
asymp. Sig. (2-tailed) & & .588 \\
\hline
\end{tabular}

Test distribution is Normal.

Source: SPSS processed data, 2016

From the results of data processing in table 2, it is obtained that the Kolmogorov-Smirnov value is 0.926 and is significant at 0.358 . The significance value is greater than 0.05 , then $\mathrm{H} 0$ is accepted, which means the residual data is normally distributed. The normally distributed data can also be seen through histogram graphs and normal data plot graphs.

Histogram

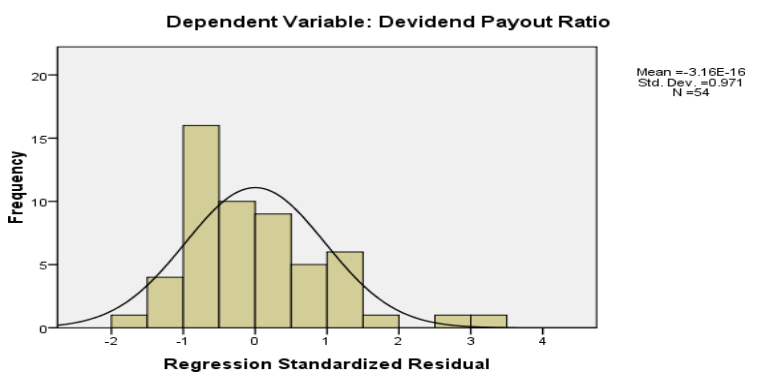

Figure 1. Histogram

The histogram graph in Figure 1 shows a normal distribution pattern because the graph is neither left skewed nor right skewed. Thus it can be concluded that the regression model has met the assumption of normality. Similarly, the results of the normality test using the normal p-plot graph. 


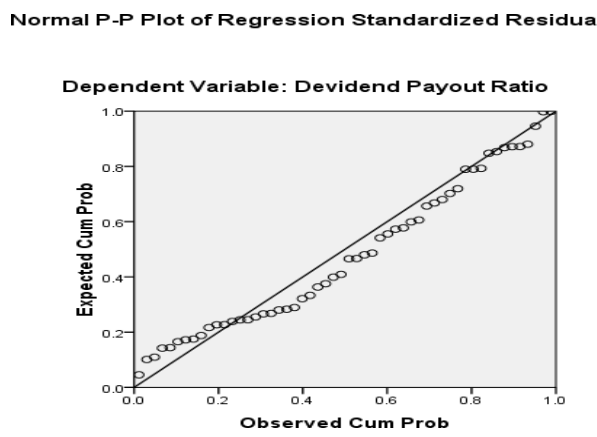

Figure 2. P-Plot Normal Graph

In Figure 2 the normal p-plot graph shows that the data spreads around the diagonal line and follows the direction of the diagonal line, it can be concluded that the regression model has met the assumption of normality.

\section{d. Multicollinearity Test}

The multicollinearity test aims to test whether there is a correlation between the independent variables in the regression model. If multicollinearity occurs in the regression model, then the regression coefficient cannot be estimated and the standard error value becomes infinity. Detection of multicollinearity in a model can be seen, namely if the Variance Inflation Factor (VIF) value is not more than 10 and the Tolerance value is more than 0.1 , the model can be said to be free from multicollinearity (Priyatno, 2013:56).

Table 3. Multicollinearity Test Results Coefficientsa

\begin{tabular}{ccccrr}
\hline & Unstandardized Coefficients & \multicolumn{2}{c}{$\begin{array}{c}\text { Standardized } \\
\text { Coefficients }\end{array}$} & \multicolumn{2}{c}{$\begin{array}{c}\text { Collinearity Statistics } \\
\text { Model }\end{array}$} \\
& B & Std. Error & Beta & Tolerane & VIF \\
\hline (Constant) & 37,442 & 5.140 & & .921 & 1.086 \\
CR & -.002 & .012 & -.017 & .866 & 1.154 \\
SIZE & -.691 & .285 & -.347 & .895 & 1.118 \\
ROA & -170 & .289 & -.083 & & \\
\hline
\end{tabular}

From the data in Table 3, it can be concluded that there is no symptom of multicollinearity between the independent variables as indicated by the tolerance value of each independent variable greater than 0.1 and the VIF value less than 10 .

\section{e. Heteroscedasticity Test}

The heteroscedasticity test aims to see whether in the regression model there is an inequality of variables from the residual of one observation to another observation. A good regression model is that there is no heteroscedasticity. According to Nugroho (2005:62) how to predict the presence or absence of heteroscedasticity in a model can be seen from the scatterplot image pattern of the model. The analysis on the Scatterplot image which states that the multiple linear regression model does not have heteroscedasticity if:

1) The data points spread above and below or around the number 0 ,

2) The data points do not collect just above or below,

3) The spread of data points must not form a wavy pattern that widens then narrows and widens again,

4) The spread of data points should not be patterned 


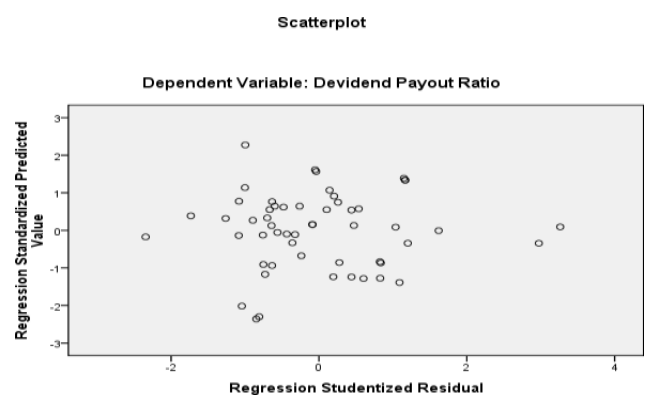

Figure 3. Heteroscedasticity Test Results (Scatterplot)

\section{f. Autocorrelation Test}

The autocorrelation test aims to test whether there is a correlation between the confounding error in a period and the confounding error of the previous period in the regression model. If there is autocorrelation in the regression model, it means that the correlation coefficient obtained is inaccurate, so that a good regression model is a regression model that is free from autocorrelation. The way to detect the presence or absence of autocorrelation is to perform the Durbin Watson (DW) test, there is no autocorrelation if the value of $d u<d w<4-d u$.

Table 4. Autocorrelation Test Results

Model Summaryb

\begin{tabular}{cccccc}
\hline Model & $\mathrm{R}$ & $\mathrm{R}$ Square & Adjusted R Square & $\begin{array}{c}\text { Std. Error of the } \\
\text { Estimate }\end{array}$ & Durbin-Watson \\
\hline 1 & $.339 \mathrm{a}$ & .115 & .062 & 9,191 & 1,693 \\
\hline
\end{tabular}

Source: SPSS processed data, 2016

Table 4 presents the results of the Durbin Watson test using the SPSS program. The results of the autocorrelation test above show the Durbin Watson statistical value (dw) of 1,693. This value will be compared with the table value using a significance of $5 \%$, the number of observations $(n)$ is 54 , and the number of independent variables is $3(k=3)$.

\subsection{Multiple Regression Analysis}

Table 5. presents the value of the regression coefficient, as well as the value of the t statistic for partial effect testing.

Table 5. Multiple Regression Test Results Coefficientsa

\begin{tabular}{cccccc}
\hline Model & \multicolumn{2}{c}{ Unstandardized Coefficients } & $\begin{array}{c}\text { Standardized } \\
\text { Coefficients }\end{array}$ & $\mathrm{t}$ & Sig. \\
& $\mathrm{B}$ & Std. Error & Beta & & \\
\hline (Constant) & 37,442 & 5.140 & & 7.285 & .000 \\
ROA & -.002 & .012 & -.017 & -.125 & .901 \\
CR & .691 & .285 & -.347 & 2.424 & .019 \\
SIZE & -170 & .289 & -.083 & -.587 & .560 \\
\hline Source: SPSS processed data, 2016
\end{tabular}

To test the hypothesis, the researcher used multiple regression analysis. The data is processed using the SPSS program. Based on the results of data processing with the SPSS program, the following results were obtained:

\section{a. Simultaneous Significance Test (F-Test)}

This test is conducted to determine whether all independent variables have a joint influence on the dependent variable. To find out whether there is a simultaneous significant effect between audit committee independence, audit committee size, audit committee competence, number of audit committee meetings, and sales growth on earnings management in Manufacturing companies 
listed on the Indonesia Stock Exchange, it can be done by looking at the level of significance ( $\alpha$ ) ) $=5 \%$. Simultaneous test results through SPSS processing can be seen in the following table:

Table 6. F-Test Results ANOVAb

\begin{tabular}{ccccccc}
\hline & Model & Sum of Squares & $\mathrm{df}$ & Mean Square & $\mathrm{F}$ & Sig. \\
\hline 1 & Regression & 547,285 & 3 & 182,428 & 2.160 & $.104 a$ \\
& Residual & 4223,853 & 50 & 84,477 & & \\
& Total & 4771,138 & 53 & & & \\
\hline
\end{tabular}

\section{b. Partial Significance Test (t-test)}

The t-test was conducted to determine how far the influence of one independent variable on the dependent variable is partially. This test is carried out by comparing the significance of tcount with ttable with the following conditions:

1) if tcount $<\mathrm{t}$ table, then $\mathrm{HO}$ is accepted and $\mathrm{Ha}$ is rejected for $=5 \%$ or significance $>0.05$,

2) if tcount $>\mathrm{t}$ table, then $\mathrm{Ha}$ is accepted and $\mathrm{HO}$ is rejected for $=5 \%$ or significance $<0.05$.

\begin{tabular}{|c|c|c|c|c|c|c|}
\hline & \multirow[t]{2}{*}{ Model } & \multicolumn{2}{|c|}{ Unstandardized Coefficients } & \multirow{2}{*}{$\begin{array}{c}\text { Standardized } \\
\text { Coefficients } \\
\text { Beta }\end{array}$} & \multirow[t]{2}{*}{$\mathrm{t}$} & \multirow[t]{2}{*}{ Sig. } \\
\hline & & B & Std. Error & & & \\
\hline \multirow[t]{4}{*}{1} & (Constant) & 37,442 & 5.140 & & 7.285 & .000 \\
\hline & CR & -.002 & .012 & -.017 & -.125 & .901 \\
\hline & SIZE & .691 & .285 & -.347 & 2.424 & .019 \\
\hline & ROA & -170 & .289 & -.083 & -.587 & .560 \\
\hline
\end{tabular}

Statistical test results $t$ The calculation in Table 7 can be explained as follows:

1) Testing on the cash ratio variable. Based on Table 7, it can be determined that the cash ratio variable has no effect on the dividend pay-out ratio with a significance level of 0.901 . Thus, $\mathrm{HO}$ is accepted, meaning that the cash ratio variable partially has no effect on the dividend pay-out ratio in BUMN companies on the Indonesia Stock Exchange in 2013-2015 at a 95\% confidence level.

2) Testing on firm size. variable. Based on Table 7, it can be determined that the firm size variable has an effect on the dividend pay-out ratio with a significance level of 0.019 . Thus, $\mathrm{HO}$ is accepted, meaning that the firm size variable partially affects the dividend pay-out ratio in BUMN companies on the Indonesia Stock Exchange in 2013-2015 at a $95 \%$ confidence level.

\section{c. Coefficient of Determination (R2)}

The value of the correlation coefficient $R$ shows how big the correlation or relationship between the independent variables and the dependent variable. The correlation coefficient is said to be strong if the $R$ value is above 0.5 and close to 1 .

Coefficient determination $\left(R^{2}\right)$ showhow much big variable independent explains the dependent variable. The adjusted $R$ square value is zero to one. If the adjusted $R$ square value is getting closer to one, then the independent variables provide all the information needed to predict the dependent variable. On the other hand, the smaller the adjusted $\mathrm{R}$ square value, the more limited the ability of the independent variables in explaining the variation of the dependent variable. The adjusted $R$ square value has a weakness, namely the adjusted $R$ square value will increase every time there is an addition of one independent variable even though the independent variable has no significant effect on the dependent variable. 
Table 8. The Result of the Coefficient of Determination Model Summaryb

\begin{tabular}{cccccc}
\hline Model & $\mathrm{R}$ & $\mathrm{R}$ Square & Adjusted R Square & $\begin{array}{c}\text { Std. Error of the } \\
\text { Estimate }\end{array}$ & Durbin-Watson \\
\hline 1 & $.339 \mathrm{a}$ & .115 & .062 & 9,191 & 1,693 \\
\hline Source: SPSS processed data 2016 & & &
\end{tabular}

Source: SPSS processed data, 2016

The value of Adjusted $\mathrm{R}$ Square in Table 8 shows the relationship between the variables of cash ratio, firm size and return on assets to the dividend pay-out ratio of 0.062 or equal to $62 \%$, which means it has a high level of relationship. Thus the variable cash ratio, firm size and return on assets simultaneously are able to provide an explanation of the dividend pay-out ratio of $62 \%$ and the rest is influenced by other variables outside of this research variable.

\section{CONCLUSION}

Based on the results of hypothesis testing, it shows that simultaneously cash ratio, firm size and return on assets have no effect on the dividend pay-out ratio, where the significance level is greater than $5 \%$, so the hypothesis is rejected.

Based on the results of hypothesis testing, partially cash ratio and return on assets have no effect on dividend pay-out where the significance level is greater than $5 \%$. So the hypothesis is rejected.

While the firm size variable has a partial effect on dividend pay-out with a significant level less than $5 \%$.

\section{REFERENCES}

Ang, Robert. 1997. Buku Pintar Pasar Modal Indonesia. Jakarta: Indonesia. Mediasoft.

Anil, Kanwal and Kapoor, Sujana. 2008. "Determinants of Dividend Payout Ratios-A Study of Indian Information Technology Sector". International Research Journal of Finance and Economics - Issue 15 (2008).p.63-71.

Atika Jauhari Hatta. 2002. Faktor-Faktor yang Mempengaruhi Kebijakan Dividen: Investigasi Pengaruh Teori Stakeholder. JAAI Volume 6 No. 2, Desember 2002.

Bagus Laksono.2006. "Analisis Pengaruh Return On Asset, Sales Growth, Asset Growth, Cash Flow dan Likuiditas terhadap Dividend Payout Ratio ( perbandingan pada perusahaan Multi National Company dan Domestic Corporation yang listed di bursa Efek Jakrta Peride 2002-2004)". Tesis. Universitas Diponegoro.

Baridwan, Zaky. 2004. Intermediate Accounting. Yogyakarta: BPFE UGM. Brigham, Eugene F. and Gapenski Louise C. 1996). Intermediate Financial Management, 5 th Edition, New York: The Dryden Press.

Brigham, Eugene dan Joel F Houston, 2001. Manajemen Keuangan II. Jakarta: Salemba Empat.

Chasanah, Amalia Nur. 2008. "Faktor - Faktor yang Mempengaruhi Dividend Payout Ratio (DPR) Pada Perusahaan yang Listed di Bursa Efek Indonesia". Thesis. Semarang: Universitas Diponegoro.

Darmadji, Tjiptono \& Fakhrudin, 2006, Pasar Modal di Indonesia : Pendekatan Tanya Jawabm Edisi, Pertama, Salemba Empat, Jakarta

Farinha, J. 2002. "Dividen d Policy, Corporate Governance and The Managerial Entrenchment Hypothesis: An Empirical Analysis". Journal of Financial Research.

Firmansyah, Tri Yoga. 2011. Analisis Pengaruh Cash Position, Debt to Equity Ratio, Return On Assets Terhadap Dividen Payout Ratio. Jurnal tidak diterbitkan. Semarang: Universitas Dian Nuswantoro.

Ghozali, Imam. 2009. Multivariate Lanjutan dengan Program SPSS. Semarang: Badan Penerbit Universitas Diponegoro.

Gugler, K., \& Yurtoglu, BB. 2003. Corporate Governance and Dividend Pay out Policy in Germany. European Economic Review 47;731-758.

Hanafi, Mamduh, M., 2004. Manajemen Keuangan, Edisi 2004/2005. Yogyakarta: Badan Penerbit Fakultas Ekonomi-UGM.

Husnan, Suad, 2000. Manajemen Keuangan, Teori dan Penerapan, Edisi Ketiga. Yogyakarta: BPFE Universitas Gajah Mada.

Kadir, Abdul. 2010. "Analisis Faktor-Faktor Yang Mempengaruhi Kebijakan Dividen Pada Perusahaan Credit Agencies Go Public Di Bursa Efek Indonesia". Jurnal Manajemen dan Akuntansi. Volume 11 No 1.p.1020. 
Mamduh M. Hanafi dan Abdul Halim, 2005, “Analisi Laporan Keuangan”, Yogyakarta.

Marlina, L dan Clara D.2009."Analisis Pengaruh Cash Position, Debt to Equity Ratio dan Return On Asset Terhadap Dividend Payout Ratio". Jurnal Manajemen Bisnis, Vol.2, No.1, Hal.1-6.

Michell suherli dan Sofyan Safri Harahap, 2004. "Studi Empiris Terhadap Faktor Penentu Kebijakan Jumlah Deviden", volume 4 nomor 1.

Permatasari, 2009 "Pengaruh cash ratio, return on asstes, growth, firm size, debt to equity ratio terhadap dividend payout rati". Fakultas Ekonomi UGM Yogyakarta.

Puspita, 2009 "Pengaruh cash ratio, debt to equity ratio, dan return on asstes terhadap dividend payout ratio pada perusahaan manufaktur yang terdaftar di bursa efek Indonesia". Jakarta

Robert Ang, 2007, Buku Pintar: Pasar Modal Indonesia, Mediaesoft Indonesia. Riyanto, Bambang. 2001. Dasar-Dasar Pembelanjaan Perusahaan. Yogyakarta: BPFE.

Sartono, Agus, 2001, Kepemilikan Orang Dalam (Insider Ownership), Utang, dan KebijakanDividen: Pengujian Empirik Teori Keagenan (Agency Theory), JAAI No 6 Vol 2.

Sharaks, Adel, (2005), Dividend Policy and Future Cash Flows, Finance India, Vol XIX, No.3,Seprtember, pp.901-913

Sri Sudarsi. 2002. Manajemen Keuangan, Edisi 3, Mitra Wacara, Jakarta.

Suad Husnan, 2001, Manajemen Keuangan, Keputusan Investasi dan Pembelanjaan, Edisi 2, Fakultas Ekonomi UGM Yogyakarta.

Sunarto dan Kartika, Andi. (2004). Analisis Faktor-faktor yang Mempengaruhi Dividen Kas di Bursa Efek Jakarta. Jurnal Bisnis dan Ekonomi, Vol.10, No.1:67-82. 